\title{
DIGLOSIA
}

Terakreditasi Sinta 3 | Volume 3 | Nomor 2 | Tahun 2020 | Halaman 211-220

P-ISSN 2615-725X | E-ISSN 2615-8655

http://diglosiaunmul.com/index.php/diglosia/article/view/63

\section{PENGEMBANGAN BAHAN AJAR MENULIS CERPEN DENGAN TEKNIK PARAFRASE PADA PESERTA DIDIK KELAS XI MAN 2 SAMARINDA}

\section{Development of Teaching Materials for Writing Short Story Using Paraphrasing Technique for Eleventh Grade Students of MAN 2 Samarinda}

\author{
Nurhana ${ }^{1, *}$, M. Siddik ${ }^{2}$, Ahmad Ridhani ${ }^{3}$ \\ 1,2,3 Magister Pendidikan Bahasa dan Sastra Indonesia \\ FKIP, Universitas Mulawarman \\ Pos-el korespondensi: nicanurhana@gmail.com
}

\begin{abstract}
The purposes of this research included: (1) developing teaching materials for writing short story using paraphrasing technique, (2) implementing learning to write short story using paraphrasing technique, (3) describing the feasibility of teaching materials for writing short story using paraphrasing technique. This research uses the research method of developing Willis's reflective, recursive, design, and development (R2D2) models. The method used is to produce a product and test the feasibility of the product in the form of teaching materials to write short stories with paraphrasing techniques in class XI MAN 2 Samarinda students. The results of the development of teaching materials for short story writing with paraphrasing techniques were validated by content/content experts who gave an average score of $92.04 \%$ and validation of teaching material experts obtained an average score of $95 \%$. From the validation results the experts obtained an average score of $93.52 \%$ with a very good category. Thus, the teaching material produced is very suitable for use by students of class XI. Furthermore, implementing learning to write short stories with paraphrase techniques through planning assessments conducted by observer 1 who gave an average score of $80 \%$ and observer 2 gave an average score of $93.33 \%$. The implementation of learning was given an average score of $81.73 \%$ by observer 1 and observer 2 giving an average score of $86.08 \%$. From the average score given by observers 1 and 2 states learning takes place very well. The feasibility of teaching materials for short story writing with paraphrase techniques can be seen from the results of small group pretest trials with an average value of 67.8 and 86.7 posttests and field trials with an average value of 73.75 and posttests with an average value $88.18 \%$ with a very decent category. These learning outcomes indicate that the development of teaching materials can improve student learning outcomes that can be seen from the value of achievements before and after using development. For the achievement of learning objectives that have been carried out effectively and efficiently. The assessment of the feasibility of teaching materials includes validation of the feasibility of the material/ content, the feasibility of the presentation, and the feasibility of the teaching material which includes linguistic and graphic skills. Feasibility was also demonstrated by the success in implementing the development of short story writing teaching materials by using the development of teaching materials in accordance with the plans that had been previously designed.
\end{abstract}

Keywords: teaching materials, short story, paraphrasing technique

Abstrak: Tujuan pengembangan penelitian ini antara lain: 1) mengembangkan bahan ajar menulis cerpen dengan teknik parafrase, (2) melaksanakan pembelajaran menulis cerpen dengan teknik parafrase, (3) mendeskripsikan kelayakan bahan ajar menulis cerpen dengan teknik parafrase. Penelitian ini menggunakan metode penelitian pengembangan model reflective, recursive, design, \& development (R2D2) rancangan Willis. Metode yang digunakan ini untuk menghasilkan suatu produk dan menguji kelayakan produk yang berupa bahan ajar menulis cerpen dengan teknik parafrase pada siswa kelas XI MAN 2 Samarinda. Hasil pengembangan bahan ajar menulis cerpen dengan teknik parafrase divalidasi oleh ahli materi/isi yang memberi skor rata-rata 92,04\% dan validasi ahli bahan ajar diperoleh skor rata-rata 95\%. Dari hasil validasi para ahli tersebut diperoleh hasil skor rata-rata 93,52\% dengan kategori sangat baik. Dengan demikian, bahan ajar yang dihasilkan sangat layak digunakan oleh siswa kelas XI. Selanjutnya, melaksanakan pembelajaran menulis cerpen dengan teknik parafrase melalui penilaian perencanaan yang dilakukan oleh pengamat 1 yang memberi skor rata-rata $80 \%$ dan pengamat 2 memberi skor rata-rata 93,33\%. Pelaksanaan pembelajaran diberi skor rata-rata 81,73\% oleh pengamat 1 dan pengamat 2 memberi skor rata-rata 86,08\%. Dari skor rata-rata yang diberikan oleh pengamat 1 dan 2 menyatakan pembelajaran berlangsung dengan sangat baik. Adapun kelayakan bahan ajar menulis cerpen dengan teknik parafrase dapat dilihat dari hasil uji coba kelompok kecil pretes dengan nilai rata-rata 67,8 dan 
postes 86,7 dan uji coba lapangan dengan nilai rata-rata 73,75 dan postes dengan nilai rata-rata 88,18\% dengan kategori sangat layak. Hasil belajar ini menunjukkan bahwa pengembangan bahan ajar mampu meningkatkan hasil belajar siswa yang dapat dilihat dari nilai capaian sebelum dan sesudah menggunakan pengembangan. Untuk pencapaian tujuan pembelajaran yang telah dilakukan secara efektif dan efesien. Penilaian kelayakan bahan ajar ini meliputi validasi kelayakan materi/isi, kelayakan penyajian, dan kelayakan bahan ajar yang meliputi kebahasaan dan kegrafikan. Kelayakan juga ditandai oleh keberhasilan dalam pelaksanaan pengembangan bahan ajar menulis cerpen dengan menggunakan pengembangan bahan ajar sesuai dengan perencanaan yang telah dirancang sebelumnya.

Kata kunci: bahan ajar, cerpen, teknik parafrase

\section{A. PENDAHULUAN}

Keterampilan berbahasa ada empat aspek yang harus dikuasai oleh peserta didik dalam pembelajaran bahasa Indonesia di sekolah atau madrasah mulai dari tingkat sekolah dasar (SD/MI) hingga perguruan tinggi (PT). Empat keterampilan berbahasa. tersebut meliputi menyimak, berbicara, membaca dan menulis (Bintari, Sudiana, \& Putrayasa, 2014). Keempat keterampilan tersebut sangat erat hubungannya karena merupakan satu kesatuan yang utuh. Pembelajaran Bahasa Indonesia diarahkan untuk mencapai keempat keterampilan tersebut yang harus dikuasai oleh peserta didik (Zulaeha, 2013). Hal tersebut sesuai dengan pendapat Tarigan (2008) menyatakan bahwa pembelajaran bahasa Indonesia tidak boleh terlepas dari empat komponen yang terlibat dalam keterampilan berbahasa. Empat komponen tersebut adalah keterampilan menyimak, keterampilan berbicara, keterampilan membaca, dan keterampilan menulis (Dalle, 2015). Empat keterampilan itu harus dikuasai apabila ingin benar-benar terampil berbahasa karena pada hakikatnya keterampilan itu erat hubungannya dengan proses berpikir yang mendasari Bahasa (Farboy, 2013).

Masalah-masalah yang sering kali dihadapi guru dalam proses belajar mengajar salah satunya adalah ketepatan memilih bahan ajar atau materi pembelajaran guna membantu peserta didik mencapai kompetensi yang diharapkan (Suryani, 2015). Hal tersebut disebabkan oleh kenyataan bahwa dalam kurikulum atau silabus materi bahan ajar hanya dituliskan secara garis besar dalam bentuk materi pokok. Buku paket yang disediakan oleh pemerintah agak sulit dipahami oleh peserta didik sementara peserta didik dilarang untuk membeli buku paket yang sekiranya sesuai dengan silabus dan mudah dipahami (Insani, 2016). Oleh karena itu, tugas gurulah untuk menjabarkan materi pokok tersebut sehingga menjadi bahan ajar yang lengkap dan mudah dipahami oleh peserta didik (Hamid, 2017).

Adapun fokus penelitian yang dilakukan adalah pembelajaran menulis cerpen yang masuk dalam kegiatan bersastra yang bertujuan untuk meningkatkan kemampuan peserta didik dalam menikmati, menghayati, dan memahami karya sastra khususnya cerpen. Agar dapat meningkatkan kemampuan peserta didik tersebut, dibutuhkan minat peserta didik dalam pembelajaran menulis cerpen. Berda-sarkan hasil wawancara kepada beberapa guru mengenai materi menulis cerpen, dikemukakan bahwa masih banyak peserta didik yang kurang memiliki minat dalam hal menulis cerpen. Hal tersebut disebabkan oleh minimnya minat peserta didik dalam menulis cerpen karena kurangnya sarana dan prasarana seperti buku bacaan yang sesuai umur peserta didik, antalogi cerpen, dan sebagainya. Selain itu, pembelajaran menulis cerpen yang dilaksanakan guru cenderung menggunakan metode atau teknik pembelajaran yang monoton. Hal inilah yang akhirnya membuat peserta didik kurang tertarik dengan kegiatan menulis cerpen. Oleh karena itu, dibutuhkan teknik dan bahan ajar baru 
untuk menanggulangi kurangnya minat peserta didik dalam menulis cerpen tersebut.

Buku ajar ini mempunyai peranan penting untuk mengembangkan aspek kognitif (pengetahuan) peserta didik, afektif (kepekaan) peserta didik, sosial, psikomotorik, serta mengembangkan karakter berani, kritis, dan kreatif peserta didik. Alasan kedua, buku ajar ini mengembangkan aspek menulis cerpen dikarenakan menulis merupakan suatu keterampilan berbahasa yang sangat penting bagi peserta didik. Dengan menulis, peserta didik dapat berkomunikasi tanpa harus bertemu langsung dengan lawan bicara. Selain itu, peserta didik juga dapat berkarya melalui tulisan, yakni dengan menulis cerita pendek, novel, makalah, drama, cerpen, dan lainnya. Pengembangan bahan ajar ini bererientasi pada Kurikulum 2013 yang menekankan pembentukan karakter karena selain mengembangkan ilmu dan pengetahuan peserta didik, pendidikan juga dituntut untuk membentuk moral dan karakter peserta didik yang baik, berani, kritis, dan kreatif merupakan karakter yang wajib dikembangkan sejak dini agar peserta didik mampu dan berani menunjukkan serta mengembangkan bakat-bakat kreatif yang ada pada diri mereka. Unsur pembentukan karakter berani, kritis, dan kreatif peserta didik diletakkan pada kegiatan pembelajaran, materi, contoh soal, serta evaluasi soal yang diberikan kepada peserta didik (Wulandari, 2015).

Berdasarkan studi pendahuluan yang dilakukan di MAN 2 Samarinda, ditemukan beberapa masalah mengenai pengadaan bahan ajar. Seiring dengan pergantian kurikulum KTSP menjadi Kurikulum 2013, bahan ajar yang digunakan dalam pembelajaran, khususnya mata pelajaran Bahasa Indonesia hanya menggunakan satu bahan ajar utama, yaitu bahan ajar berjudul Bahasa Indonesia yang diperuntukkan bagi peserta didik kelas XI. Bahan ajar tersebut adalah bahan ajar yang diproduksi oleh tim dari Kementerian Pendidikan dan Kebudayaan Republik Indonesia Revisi Tahun 2017. Namun, berdasarkan wawancara dengan guru mata pelajaran Bahasa Indonesia yang menggunakan bahan ajar tersebut diketahui bahwa masih ada beberapa kesalahan konsep pada materinya. Guru juga masih mengandalkan referensi dari bahan ajar kurikulum lama dan sumber lain seperti internet. Selain itu, guru juga belum berkeinginan untuk mengembangkan bahan ajar baru dengan alasan kurikulum yang digunakan sekarang isinya masih sering berganti.

Terkait dengan penelitian ini penulis terdorong untuk melakukan pengembangan bahan ajar dengan materi menulis cerpen. Pengembangan bahan ajar menulis cerpen diintegrasikan dengan teknik parafrase. Parafrase adalah istilah linguistik yang berarti pengungkapan kembali suatu konsep dengan cara lain dalam bahasa yang sama, namun tanpa mengubah maknanya. Jika parafrase lagu artinya mengubah lagu menjadi bentuk prosa yang tunduk pada aturan-aturan prosa tanpa mengubah maksud dari isi lagu tersebut (Ayulinda, 2009, hal. 133). Parafrase memberikan kemungkinan kepada sang penulis untuk memberi penekanan yang agak berlainan dengan penulis asli. Dalam penelitian ini mem-fokuskan pada penggunaan media lagu untuk merangsang siswa dalam menuang-kan imajinasi, gagasan, dan pikirannya dalam kegiatan pembelajaran yang dituangkan dalam bentuk bahasa tulis. Media lagu sebagai salah satu media audio merupakan alat bantu dalam penyam-paian bahan ajar dalam menulis cerita pendek dengan teknik parafrase syair lagu kepada siswa. Memparafrasekan lagu artinya mengubah lagu menjadi bentuk prosa/narasi tanpa mengurangi inti/makna dari lagu tersebut. 


\section{B. METODE}

Penelitian ini menggunakan model pengembangan untuk menghasilkan produk tertentu berupa bahan ajar yang didasarkan pada pengembangan model reflektif, rekursif, desain, dan developmen (R2D2), model rancangan Willis (dalam Siddik, 2009). Langkah penelitian pengembangan model R2D2 tersebut dapat dilihat pada bagan 1 berikut.

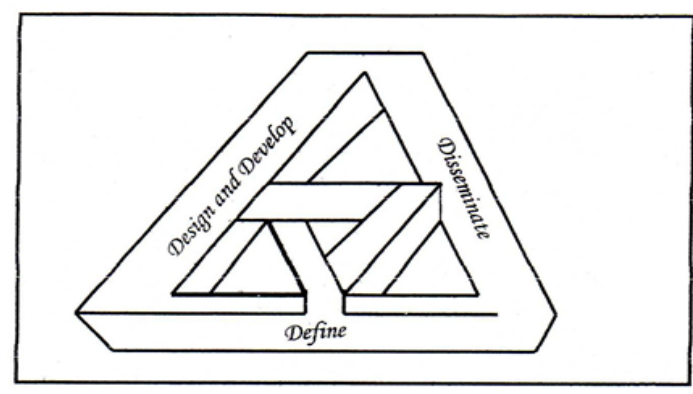

\section{Gambar 1. Model Desain R2D2}

Model ini terdiri dari tiga langkah. Langkah pertama fokus pendefinisian meliputi: (a) studi pendahuluan merupakan tahap awal dalam melakukan penelitian dan pengembangan bahan ajar. Pada tahap ini, penulis melakukan observasi dan mengumpulkan data-data terkait dengan penerapan bahan ajar menulis cerpen dengan teknik parafrase lagu di kelas XI MAN 2 Samarinda. Datadata yang perlu digali oleh penulis adalah data mengenai teknik menulis cerpen yang meliputi perencanaan pembelajaran, pelaksanaan pembelajaran, penugasan, sarana prasarana dan faktor-faktor yang mendukungnya. b) Pembentukan tim kolaboratif, penulis melibatkan sebanyak mungkin pihak yang terkait melalui diskusi dan konsultasi yang progresif. Pihak-pihak yang dilibatkan secara aktif terdiri atas (1) ahli menulis novel, (2) ahli desain bahan ajar, (3) pengamat dari teman sejawat dua orang, kedua dosen pembimbing, dan peserta didik kelas XI Bahasa. Langkah kedua fokus desain dan pengembangan, berfokus pada pem-buatan bahan ajar menulis cerpen dengan teknik parafrase pada peserta didik melalui uji bahan ajar, uji ahli dan praktisi di lapangan. Langkah ketiga Penye-barluasan dilakukan melalui penyajian produk akhir bahan ajar. Penyebaran bahan ajar tersebut diberikan ke perpustakaan sekolah agar dapat dibaca oleh para guru khususnya buku pengangan guru yang bertujuan memberikan informasi kepada praktisi dengan harapan dapat meningkatkan kinerja dan pada akhirnya dapat meningkatkan mutu pendidikan. Demi-kian pula dengan buku siswa agar dibaca oleh siswa yang bertujuan memberikan informasi dengan harapan dapat meningkatkan prestasi belajar siswa dalam hal menulis cerpen. Adapun instrumen pengumpulan data dalam penelitian ini berupa panduan wawancara, pedoman catatan lapangan, panduan angket, dan lembar observasi.

Data yang sudah terkumpul dianalisis untuk mengetahui hasil pemerolehan nilai para ahli terhadap produk yang dihasilkan. Hasil analisis tersebut digunakan untuk merevisi produk awal pengembangan bahan ajar dan digunakan untuk uji coba lapangan atau kelompok besar. Lembar validitas berupa perolehan data tentang penilaian bahan ajar menulis cerpen dengan teknik parafrase dari ahli materi, ahli bahan ajar, respons minat siswa, penilaian perencanaan dan pelak-sanaan pembelajaran dari guru mata pelajaran bahasa Indonesia. Hasil analisis tersebut dijelaskan dalam bentuk deskriptif. Teknik analisis ini digunakan untuk mengolah data yang diperoleh dalam bentuk deskriptif persentase.

Lembar validasi atau angket dalam penelitian ini digunakan untuk menilai atau mengukur kefektifan bahan ajar yang dikembangkan yakni bahan ajar menulis cerpen dengan teknik parafrase. Untuk memudahkan penilaian kualitatif menjadi kuantitatif maka penulis menggunakan penilaian dengan menentukan skor pilihan jawaban angket menggunakan skala likert. Adapun kriteria pemberian skor untuk 
alternatif jawaban untuk setiap item yang dapat dilihat pada Tabel 1.

Tabel 1. Ketentuan Pemberian Skor

\begin{tabular}{lc}
\hline \multicolumn{1}{c}{ Kategori } & Skor \\
\hline SB (Sangat Baik) & 4 \\
B (Baik) & 3 \\
TB (Tidak Baik) & 2 \\
STB (Sangat Tidak Baik) & 1 \\
\hline
\end{tabular}

Sumber: Sugiono (2015, hal. 135)

\section{PEMBAHASAN}

Penelitian ini merupakan penelitian yang dilakukan untuk pengembangan bahan ajar menulis cerpen dengan teknik parafrase siswa kelas XI. Dalam pengembangan bahan ajar ini diperlukan tahapan prosedur penelitian yang harus dilakukan agar produk pengembangan bahan ajar yang dihasilkan sesuai dengan tujuan dan sasaran dalam penggunaannya. Berikut ini diuraikan mengenai tahapan dan hasil penelitian yang telah dilakukan.

Pengembangan bahan ajar menulis cerpen dengan teknik parafrase pada siswa kelas XI MAN 2 Samarinda menghasilkan sebuah produk. Produk tersebut divalidasi oleh ahli materi/isi, validasi ahli bahan ajar, dan validasi praktisi pendidikan. Dengan validator yang berkompeten dan menguasai pada bidangnya masingmasing. Validator diharapkan mampu memberi masukan/saran untuk menyempurnakan pengembangan bahan ajar menulis cerpen. Selanjutnya dilakukan revisi desain berdasarkan saran-saran yang diberikan oleh validator pada saat validasi untuk menghasilkan produk pengembangan yang layak. Validasi ahli materi mengenai kelayakan isi/materi memberikan nilai rata-rata 93,33\% dengan kategori sangat layak dan kelayakan penyajian diberi nilai $90,75 \%$ dengan kategori sangat layak. Ahli bahan ajar memberikan nilai rata-rata 95\% dengan kategori sangat layak, dan praktisi pendidikan memberikan penilaian $87,5 \%$ dengan kategori yang sama yakni sangat layak. Dengan demikian validasi dilakukan hanya satu kali karena hasil validasi sudah sangat layak. Dari hasil validasi tersebut menghasilkan sebuah produk berupa buku sebagai pegangan guru dan buku siswa yang terdiri, halaman judul, kata pengantar, daftar isi, kompetensi dasar dan tujuan pembelajaran. Bagian I Kegiatan 1 Pengenalan Cerpen, meliputi: pengertian cerpen, unsur-unsur cerpen, struktur cerpen, bahasa cerpen, tahapan-tahapan menulis. Bagian II Kegiatan 2 Membangun Konteks, meliputi: pengertian parafrase, tahapan teknik parafrase, syair lagu, draf cerita pende, dan tugas untuk siswa. Bagian III Kegiatan 3 Menulis Cerpen dengan Teknik Parafrase, meliputi: penerapan teknik parafrase, contoh cerpen dengan teknik parafrase, dan penugasan. Buku siswa diakhiri dengan daftar pustaka. Perbedaan antara buku guru dengan buku siswa hanya pada silabus dan RPP yang terdapat pada buku pegangan guru.

Pelaksanaan pembelajaran menulis cerpen dengan teknik parafrase diarahkan pada pencapaian perencanaan dan pelaksanaan pembelajaran yaitu pencapaian waktu ideal yang digunakan untuk melakukan setiap kegiatan yang termuat dalam rencana pelaksanaan pembelajaran (RPP). Dasar yang digunakan adalah dengan melihat hasil penilaian RPP dan pelaksanaan pembelajaran yaitu lembar APKG 1 dan APKG 2.

Hasil yang diperoleh dari pengamat 1 dan 2 pada perencanaan dan pelaksanaan pembelajaran dapat dilihat pada Tabel 2 . 
Tabel 2. Hasil Penilaian Pelaksanaan Pembelajaran Bahasa Indonesia Pengamat 1 dan Pengamat 2

\begin{tabular}{cl} 
No. & \multicolumn{1}{c}{$\begin{array}{c}\text { Aspek-Aspek Penilaian } \\
\text { Perencanaan }\end{array}$} \\
1 & $\begin{array}{l}\text { Prapembelajaran } \\
2\end{array}$ \\
3 & $\begin{array}{l}\text { Inti: penguasaan materi ajar } \\
\text { Teknik pembelajaran }\end{array}$ \\
4 & $\begin{array}{l}\text { Pemanfaatan sumber } \\
\text { belajar/media pembelajaran }\end{array}$ \\
5 & $\begin{array}{l}\text { Pembelajaran yang } \\
\text { memotivasi dan memelihara }\end{array}$ \\
& $\begin{array}{l}\text { keterlibatan siswa } \\
6\end{array}$ \\
& $\begin{array}{l}\text { Penilaian proses dan hasil } \\
\text { belajar }\end{array}$ \\
7 & $\begin{array}{l}\text { Pengunaan bahasa } \\
\text { Penutup } \\
\text { Rata-rata }\end{array}$
\end{tabular}

Berdasarkan penilaian yang telah dilakukan oleh pengamat mengenai pembelajaran yang telah dilakukan penulis diperoleh hasil $80 \%$ dari pengamat 1 dan 2 untuk aspek prapembelajaran dan berkategori baik. Persentase $80 \%$ dari pengamat 1 dan $85 \%$ dari pengamat 2 untuk aspek kegiatan inti pembelajaran dalam penguasaan materi ajar dengan kategori baik dan sangat baik. Pada aspek teknik pembelajaran memeroleh kategori sangat baik dengan persentase $88 \%$ dari pengamat 1 dan kategori baik dengan nilai $80 \%$ dari pengamat 2. Aspek Pemanfaatan sumber belajar/media pembelajaran memeroleh skor yang sama sebesar $80 \%$ dari pengamat 1 dan pengamat 2 dengan kategori sangat baik. Persentase $80 \%$ dari pengamat 1 dan 2 pada aspek pembelajaran yang memotivasi dan memelihara keterlibatan siswa khusus dan berkategori baik.

Melaksanakan penilaian proses dan hasil belajar mendapatkan skor $80 \%$ dari pengamat 1 dan $90 \%$ oleh pengamat 2

$\begin{array}{ccc}\text { Ket. } & \text { Pengamat } 2 & \text { Ket. } \\ \text { Baik } & 80 \% & \begin{array}{c}\text { Sangat Baik } \\ \text { Saik }\end{array} \\ \begin{array}{c}\text { Sangat Baik } \\ \text { Baik }\end{array} & 85 \% & \text { Baik } \\ \text { Baik } & 80 \% & \text { Baik } \\ \text { Baik } & 80 \% & \\ & & \text { Baik } \\ \text { Baik } & 90 \% & \text { Sangat Baik } \\ \text { Baik } & 100 \% & \text { Sangat Baik } \\ \text { Baik } & 100 \% & \text { Sangat Baik } \\ \text { Baik } & \mathbf{8 6 , 0 8 \%} & \text { Sangat Baik }\end{array}$

dengan kategori baik dan sangat baik. Aspek penggunaan bahasa memeroleh baik dan sangat dengan nilai $80 \%$ dan $100 \%$ dari pengamat 2 dan yang terakhir pada bagian penutup ini diperoleh kategori baik/layak dan sangat baik dengan skor yang sama $80 \%$ dari pengamat 1 dan skor $100 \%$ pengamat 2 . Hasil penilaian yang telah dilakukan oleh pengamat 1 dan pengamat 2 mengenai pelaksanaan pengembangan pembelajaran menulis cerpen dengan menggunakan teknik parafrase untuk mata pelajaran Bahasa Indonesia sangat layak/baik digunakan dalam proses pembelajaran.

Kelayakan bahan ajar menulis cerpen dengan teknik parafrase ditandai oleh hasil belajar ketika uji coba bahan ajar terhadap siswa dan keberhasilan pelaksanaan pembelajaran berdasarkan perencanaan pembelajaran yang telah dilakukan.

Untuk mengetahui kelayakan pembelajaran maka penulis memerlukan teknik pengolahan data dengan mengacu pada hasil belajar siswa sebagai berikut. 
Tabel 3. Nilai Tes Awal Menulis Cerpen Siswa pada Uji Kelompok Kecil

\begin{tabular}{cccc}
\hline No. & Nilai Pretes & Frekuensi (f) & Persentase \\
\hline 1 & 82 & 1 & $12,09 \%$ \\
2 & 80 & 1 & $11,79 \%$ \\
3 & 76 & 1 & $11,20 \%$ \\
4 & 72 & 2 & $10,61 \%$ \\
5 & 60 & 3 & $09,14 \%$ \\
6 & 55 & 2 & $08,11 \%$ \\
\hline Jumlah & $\mathbf{6 7 8}$ & $\mathbf{1 0}$ & $\mathbf{1 0 0} \%$ \\
\hline
\end{tabular}

Nilai pretes tertinggi siswa berdasarkan tabel di atas sebagai berikut. 82 yang diperoleh satu orang siswa $(, 12,09 \%)$. Secara rinci, pemerolehan nilai setiap sampel yaitu, sampel yang memperoleh nilai 80 berjumlah satu orang $(11,79 \%)$; yang memperoleh 76 berjumlah satu orang siswa (11,20\%); yang memperoleh nilai 72 berjumlah dua orang siswa (09,14\%); yang memperoleh nilai 60 tiga, dan memperoleh nilai 55 sebanyak dua orang siswa $(08,11 \%)$; yang memperoleh 76 berjumlah satu orang siswa (11,20\%); yang memperoleh nilai 72 berjumlah dua orang siswa $(09,14 \%)$; yang memperoleh nilai 60 tiga, dan memperoleh nilai 55 sebanyak dua orang siswa $(08,11 \%)$. Dari tabel tersebut diketahui nilai rata-rata pretes kemampuan menulis cerpen uji kelompok kecil pada siswa kelas XI Bahasa MAN 2 Samarinda yang melibatkan 10 siswa adalah 67,8. Nilai tersebut diperoleh dengan menggunakan rumus sebagai berikut.

$$
\begin{aligned}
\bar{x} & =\frac{\sum x}{N} \\
& =\frac{678}{10} \\
\dot{X} & =67,8
\end{aligned}
$$

Penyajian data postes bertujuan mengukur kemampuan menulis cerpen pada uji kelompok kecil dapat dilihat pada Tabel 4.

Tabel 4. Nilai Tes Akhir Menulis Cerpen Siswa pada Uji Kelompok Kecil

\begin{tabular}{cccc}
\hline No. & Nilai Postes & Frekuensi (f) & Persentase \\
\hline 1 & 90 & 1 & $10,46 \%$ \\
2 & 89 & 1 & $10,34 \%$ \\
3 & 88 & 1 & $10,23 \%$ \\
4 & 87 & 3 & $10,11 \%$ \\
5 & 86 & 2 & $10 \%$ \\
6 & 85 & 1 & $9,88 \%$ \\
7 & 75 & 1 & $8,72 \%$ \\
\hline Jumlah & $\mathbf{8 6 0}$ & $\mathbf{1 0}$ & $\mathbf{1 0 0} \%$ \\
\hline
\end{tabular}

Secara rinci, perolehan skor tiap sampel, skor tertinggi yaitu 90 yang dicapai oleh satu orang $(10,46 \%)$; yang memperoleh skor 89 berjumlah satu orang $(10,34 \%)$; yang memperoleh skor 88 berjumlah satu orang (10,23\%); yang memperoleh skor 87 berjumlah tiga orang $(10,11 \%)$; yang memperoleh skor 86 berjumlah dua orang (10\%); yang memperoleh skor 85 berjumlah satu orang $(9,88 \%)$. yang memperoleh nilai 75 berjumlah satu orang $(8,72 \%)$. Nilai siswa berada pada rentang 75 sampai dengan 93 . Terjadi peningkatan prestasi belajar siswa dalam menulis cerpen dengan teknik parafrase. 
Tabel 5. Hasil Belajar Siswa dengan Pengembangan Bahan Ajar Menulis Cerpen dengan Teknik Parafrase

\begin{tabular}{|c|c|c|c|c|c|c|c|c|c|c|}
\hline \multirow{3}{*}{ No. } & \multirow{3}{*}{ Nama } & \multicolumn{7}{|c|}{ Aspek Penilaian } & \multirow{2}{*}{ Jumlah } & \multirow{3}{*}{ KET. } \\
\hline & & 1 & 2 & 3 & 4 & 5 & 6 & 7 & & \\
\hline & & 12 & 12 & 12 & 20 & 12 & 12 & 20 & 100 & \\
\hline 1 & Achmad Suryadi & 12 & 12 & 10 & 18 & 10 & 10 & 20 & 92 & Tuntas \\
\hline 2 & Ade Sunán Bimantara & 10 & 12 & 10 & 14 & 10 & 10 & 18 & 84 & Tuntas \\
\hline 3 & Ailsa Purwabhagawanta S. L. & 10 & 10 & 10 & 18 & 12 & 10 & 18 & 88 & Tuntas \\
\hline 4 & Amalia Kusrun & 12 & 12 & 12 & 18 & 12 & 12 & 15 & 93 & Tuntas \\
\hline 4 & Sandra Putri A & 10 & 12 & 10 & 15 & 10 & 10 & 16 & 83 & Tuntas \\
\hline 5 & Ariana Mayra Kamma & 10 & 12 & 10 & 14 & 12 & 12 & 18 & 88 & Tuntas \\
\hline 6 & Arya Nur Ramadhan & 12 & 12 & 12 & 20 & 10 & 10 & 20 & 96 & Tuntas \\
\hline 7 & Dea Mierela Ananda & 10 & 10 & 10 & 15 & 12 & 12 & 15 & 84 & Tuntas \\
\hline 8 & Dian Sandra Dewi & 10 & 12 & 12 & 15 & 12 & 12 & 16 & 89 & Tuntas \\
\hline 9 & Diko Adam & 12 & 12 & 12 & 18 & 10 & 12 & 20 & 96 & Tuntas \\
\hline 10 & Dina Nur Ghina Abdi & 12 & 12 & 12 & 20 & 10 & 10 & 14 & 90 & Tuntas \\
\hline 11 & Dinda Ramadhanti Zahro & 12 & 12 & 10 & 14 & 12 & 12 & 18 & 90 & Tuntas \\
\hline 12 & Farah Risky Annisa & 12 & 12 & 10 & 18 & 11 & 12 & 18 & 93 & Tuntas \\
\hline 13 & Farhan Cahya Arianto & 10 & 10 & 10 & 14 & 12 & 12 & 15 & 83 & Tuntas \\
\hline 14 & Indah Puspita Khusnul K. & 12 & 10 & 12 & 17 & 12 & 10 & 14 & 87 & Tuntas \\
\hline 15 & Jihan Nabila & 12 & 12 & 12 & 20 & 10 & 10 & 20 & 96 & Tuntas \\
\hline 16 & Kamala Hayati & 11 & 12 & 10 & 14 & 10 & 10 & 14 & 81 & Tuntas \\
\hline 17 & Khaerunnisa & 10 & 10 & 12 & 14 & 10 & 10 & 14 & 80 & Tuntas \\
\hline 18 & Latifah Aulia Rahma & 12 & 12 & 12 & 18 & 12 & 12 & 18 & 96 & Tuntas \\
\hline 19 & Lucky Purnama Sultan & 10 & 12 & 12 & 15 & 10 & 10 & 15 & 84 & Tuntas \\
\hline 20 & Maulidia Asri Khairunisa & 12 & 10 & 12 & 18 & 12 & 10 & 16 & 90 & Tuntas \\
\hline 21 & Muhammad Fadhil Athoya & 12 & 12 & 10 & 20 & 12 & 12 & 16 & 94 & Tuntas \\
\hline 22 & Muhammad Hildan & 10 & 10 & 12 & 15 & 10 & 10 & 14 & 81 & Tuntas \\
\hline 23 & M. Ridha Daudy Qasidy & 12 & 12 & 12 & 18 & 12 & 12 & 15 & 93 & Tuntas \\
\hline 24 & Muh. Syahid Abdan Syukron & 12 & 12 & 12 & 16 & 12 & 12 & 20 & 96 & Tuntas \\
\hline 25 & M. Syahril Amien Maulana & 10 & 12 & 10 & 15 & 10 & 10 & 13 & 80 & Tuntas \\
\hline 26 & Muhammad Wildan & 10 & 10 & 10 & 16 & 10 & 10 & 14 & 80 & Tuntas \\
\hline 27 & Muh. Wirayuda Burhan & 12 & 12 & 12 & 18 & 10 & 12 & 20 & 96 & Tuntas \\
\hline 28 & Nurhaliza Apriana Putri & 12 & 11 & 10 & 15 & 12 & 12 & 14 & 86 & Tuntas \\
\hline 29 & Nurisya Ghina Zhafira & 12 & 12 & 10 & 16 & 12 & 12 & 17 & 91 & Tuntas \\
\hline 30 & Puja Nurhasna Ghina S & 12 & 12 & 12 & 18 & 12 & 12 & 16 & 94 & Tuntas \\
\hline 31 & Rabiatul Adawiyah & 10 & 12 & 10 & 14 & 12 & 10 & 13 & 81 & Tuntas \\
\hline 32 & Rahmawati Bakhri & 12 & 10 & 10 & 16 & 12 & 12 & 17 & 89 & Tuntas \\
\hline 33 & Saleh & 12 & 12 & 12 & 18 & 10 & 12 & 18 & 94 & Tuntas \\
\hline 34 & Shafa Nurfakhirah Putri & 10 & 10 & 12 & 14 & 10 & 12 & 14 & 82 & Tuntas \\
\hline 35 & Siti Mutmainah Iis Yuliani & 10 & 10 & 10 & 14 & 12 & 10 & 14 & 80 & Tuntas \\
\hline 36 & Siti Nurjanah & 12 & 12 & 10 & 18 & 10 & 12 & 20 & 94 & Tuntas \\
\hline \multirow[t]{3}{*}{37} & Syarifah Jihan Zahira Alkaf & 12 & 12 & 12 & 20 & 12 & 10 & 15 & 93 & Tuntas \\
\hline & Jumlah & & & & & & & & 3263 & \\
\hline & Nilai Rata-rata & & & & & & & & 88,18 & Tuntas \\
\hline
\end{tabular}

Berdasarkan data yang diperoleh dari uji coba awal kelompok kecil dengan nilai ratarata 67,8 dan nilai akhir uji kelompok kecil meningkat menjadi 86,7. Sedangkan hasil yang dicapai pada uji awal kelompok besar atau uji lapangan nilai rata-rata 73,75 sedangkan uji akhir kelompok besar atau uji lapangan terdapat peningkatan dengan nilai rata-rata 88,18 .
Secara umum dapat disimpulkan bahwa pengembangan bahan ajar menulis cerpen mampu membawa siswa dalam mencapai kriteria ketuntasan minimal (KKM) yang berlaku yakni 75. Sedangkan respons siswa terhadap pengembangan bahan ajar pembelajaran pada kompetensi menulis cerpen sangat positif. Hal ini terungkap dari hasil angket serta komentar yang 
disampaikan siswa uji coba kelompok kecil dan uji coba kelompok besar dengan nilai yang sama rata-rata 3,5 atau $88,18 \%$ dengan kategori sangat layak. Hasil belajar ini juga telah menunjukkan bahwa pengembangan bahan ajar mampu meningkatkan hasil belajar siswa yang dapat dilihat dari nilai capaian sebelum dan sesudah menggunakan pengembangan. Kelayakan juga ditandai oleh keberhasilan dalam pelaksanaan pengembangan bahan ajar menulis cerpen dengan menggunakan pengembangan bahan ajar sesuai dengan perencanaan yang telah dirancang sebelumnya.

Secara teknis terdapat sepuluh indikator yang harus dipenuhi bahan ajar yang layak. Sepuluh indikator tersebut sebagai berikut. (1) mampu menarik minat siswa untuk mmpergunakannya, (2) mampu memberikan motivasi kepada siswa, (3) memuat ilustrasi yang menarik, (4) mempertimbangkan aspek-aspek linguistik yang meliputi: sesuai dengan tingkat perkembangan siswa, menggunakan bahasa yang komunikatif, dan pemakaian bahasa yang memenuhi syarat keruntutan dan keterpaduan alur berpikir. (5) isi bahan ajar harus berhubungan erat dengan pelajaran yang lain, (6) menimbulkan motivasi aktivitas-aktivitas pribadi para siswa yang mempergunakan bahan ajar tersebut, (7) isi harus jelas agar terhindar dari konsep yang samar-samar dan ambigu agar tidak membingungkan siswa dalam menggunakan bahan ajar tersebut, (8) memberikan pemantapan dan penekanan pada nilai-nilai anak dan orang dewasa, (9) memiliki sudut pandang yang jelas, dan (10) menghargai perbedaan-perbedaan pribadi para pemakainya.

Dalam hal kelayakan kegrafikan, ada tiga indikator yang harus diperhatikan dalam bahan ajar, yaitu: (1) ukuran buku yang tidak terlalu tebal, (2) desain kulit buku yang menarik, (3) desain isi buku yang mudah dipahami siswa.

\section{PENUTUP}

Penelitian pengembangan bahan ajar menulis cerpen dengan teknik parafrase pada siswa kelas XI MAN 2 Samarinda telah dilakukan dengan menghasilkan sebuah tahapan pelaksanaan pembelajaran yang sangat layak digunakan. Kelayakan produk ini berdasarkan hasil penilaian ahli materi mengenai kelayakan isi/materi dengan nilai $93,33 \%$ dan kelayakan penyajian diberi nilai $90,75 \%$ dengan kategori sangat layak, dari ahli bahan ajar mendapat nilai 95\% dengan kategori sangat layak, dan praktisi pendidikan memberikan penilaian $87,5 \%$ dengan kategori yang sama yakni sangat layak.

Pada rancangan perencanaan pembelajaran yang termuat dalam RPP telah dinilai oleh dua orang pengamat dan telah diperoleh skor rata-rata $84 \%$ dengan kategori baik/layak oleh pengamat 1 dan $98,06 \%$ oleh pengamat 2 dengan kategori sangat layak. Hal ini menunjukkan bahwa rencana pembelajaran menulis cerpen dengan menggunakan pengembangan pelaksanaan pembelajaran menulis cerpen sangat layak digunakan sebagai acuan dalam pelaksanaan pembelajaran. Berdasarkan pelaksanaan pembelajaran menulis cerpen yang dikembangkan telah diperoleh skor rata-rata $80 \%$ dengan kategori sangat layak oleh pengamat 1 dan pengamat 2 memberi skor 98,06 . Hal ini memberikan gambaran bahwa pembelajaran menulis cerpen dengan menggunakan pengembangan bahan ajar, pembelajaran sangat layak dilaksanakan sesuai dengan perencanaan pembelajaran yang telah dirancang.

Kelayakan pengembangan bahan ajar menulis cerpen ditandai oleh hasil belajar ketika uji coba bahan ajar terhadap siswa dan keberhasilan pelaksanaan pembelajaran berdasarkan perencanaan pembelajaran yang telah dilakukan. Berdasarkan data yang diperoleh dari uji coba awal kelompok kecil dengan nilai rata-rata 67,8 dan nilai akhir uji kelompok kecil meningkat menjadi 86. Sedangkan hasil yang dicapai pada uji awal kelompok besar atau uji lapangan nilai ratarata 73,75 sedangkan uji akhir kelompok besar atau uji lapangan terdapat peningkatan dengan nilai rata-rata 88,18. 
Berdasarkan pemaparan tersebut dapat disimpulkan bahwa baik validasi kelayakan materi/ isi, kelayakan penyajian, kelayakan kebahasaan, dan kelayakan kegrafikan berkategori sangat baik. Dengan demikian bahan ajar sangat layak digunakan oleh siswa kelas XI dalam pembelajaran menulis cerpen.

\section{DAFTAR PUSTAKA}

Bintari, N. L. G. R. P., Sudiana, I. N., \& Putrayasa, I. B. (2014). Pembelajaran Bahasa Indonesia Berdasarkan Pendekatan Saintifik (Problem Based Learning) Sesuai Kurikulum 2013 di Kelas VII SMP Negeri 2 Amlapura. Jurnal Pendidikan dan Pembelajaran Bahasa Indonesia, 3(1).

http://oldpasca.undiksha.ac.id/ejournal/index.php/jurnal_bahasa/artic le/view/1185

Dalle, H. A. (2015). Wacana Bahasa Inggris Berdasarkan Keterampilan Berbahasa Kelas X Man 2 Parepare. Al-Ishlah: Jurnal Pendidikan Islam, 13(2), 110-129. http://ejurnal.iainpare.ac.id/index.php /alislah/article/view/496

Farboy, S. (2013). Penerapan Metode Cooperative Integrated Reading and Composition (CIRC) untuk Meningkatkan Kemampuan Menemukan Gagasan Utama Sebuah Teks pada Siswa Kelas VII di SMP Negeri 3 Batu Tahun Ajaran 2008/2009. Jurnal Artikulasi, 7(1), 415431.

http://ejournal.umm.ac.id/index.php/ $\mathrm{jib} /$ article/view/1279

Hamid, A. (2017). Guru Profesional. AlFalab: Jurnal Ilmiah Keislaman dan Kemasyarakatan, 17(2), 274-285. https://ejurnal.staialfalahbjb.ac.id/inde x.php/alfalahjikk/article/view/26

Himang, V. H. (2019). Pengembangan Bahan Ajar Menulis Cerpen Berbasis
Pengalaman Siswa Kelas XI SMK. Diglosia: Jurnal Kajian Bahasa, Sastra, dan Pengajarannya, 2(2), 93-102. https://doi.org/10.30872/diglosia.v2i2 .21

Insani, M. D. (2016). Studi Pendahuluan Identifikasi Kesulitan dalam Pembelajaran Pada Guru IPA SMP SeKota Malang. Jurnal Pendidikan Biologi, 7(2), 81-93. http://journal2.um.ac.id/index.php/jp $\mathrm{b} /$ article/view/723

Nurgiyantoro, B. (2013). Teori pengkajian fiksi. Yogyakarta: Gadjah Mada Pedoman Umum Pembelajaran. Jakarta: Kemendikbud.

Siddik, M. (2009). Pengembangan Model Pembelajaran Menulis Deskripsi untuk Siswa Kelas IV Sekolah Dasar. Disertasi. Universitas Negeri Malang.

Sugiyono. (2013). Metode Penelitian Pendidikan (Pendekatan Kuantitatif, Kualitatif, dan R\&D). Bandung: Alfabeta.

Suryani, C. (2015). Implementasi Supervisi Pendidikan dalam Meningkatkan Proses Pembelajaran di MIN Sukadamai Kota Banda Aceh. Jurnal Ilmiah Didaktika: Media Ilmiah Pendidikan dan Pengajaran, 16(1), 23-42. http://dx.doi.org/10.22373/jid.v16i1.5 85

Tarigan, H. G. (2008). Menulis sebagai Suatu Keterampilan Berbahasa. Edisi Revisi. Bandung: Angkasa.

Wulandari, R. A. (2015). Sastra dalam Pembentukan Karakter Siswa. Edukasi Kultura: Jurnal Bahasa, Sastra dan Budaya, 1(2), 63-73. https://jurnal.unimed.ac.id/2012/inde x.php/kultura/article/view/5181

Zulaeha, I. (2013). Pengembangan Model Pembelajaran Keterampilan Berbahasa Indonesia Berkonteks Multikultural. Litera, 12(1), 97-105. https://doi.org/10.21831/ltr.v12i01.1 331 